\title{
Analysis of Challenges Faced by Indian Logistics Service Providers
}

\author{
Anchal Gupta \\ Delhi School of Management, Delhi Technological University, Delhi - 110042, India \\ E-mail: anchal.gupta1503@gmail.com (Corresponding Author) \\ Rajesh K. Singh \\ Management Development Institute, Gurgaon, India \\ E-mail: rksdce@yahoo.com \\ Pradeep K. Suri \\ Delhi School of Management, Delhi Technological University, Delhi 110042, India \\ E-mail: pks.suri@gmail.com
}

\begin{abstract}
In developing country like India, logistics sector is in booming stage and grabbing opportunities to grow infinitely. Currently, Logistics sector contributes around 14\% in GDP in India. Boom in e-commerce industry and initiatives like MAKE in India, will definitely bring substantial growth for Logistics Service Providers (LSPs). The LSPs need to redesign their strategies in order to grab all upcoming opportunities. Many challenges are faced by logistics service providers in order to deliver shipments on promised time and in desirable condition. Although, Government has already initiated several mega projects to support LSPs but still it is not synchronized with increased industry requirements. Fragmented and unorganized sector, Infrastructural bottlenecks and Cost implications etc. are the main challenges which come across in delivering high quality services to the end customers. In this study, it has been attempted to identify and analyze the key challenges which impede the effective service quality of logistics service providers. Based on the literature review and experts' opinion, ten key challenges faced by logistics service providers are identified. A structural relationship model is developed by using Interpretive Structural Modeling (ISM) and further challenges are categorized as drivers, dependent, autonomous and linkage variables based on their driving and dependence power with the help of MICMAC Analysis. Based on MICMAC analysis, three challenges have been identified as dependent variables, four as drivers, one as autonomous and two as linkage variables. The study is expected to provide useful inputs to practitioners and service providers itself in terms of crafting better strategies which can overcome the identified challenges and can design better solutions for delivering better service quality to their customers.
\end{abstract}

Keywords: logistics service providers, service quality, challenges, interpretive structural modeling (ISM), MICMAC Analysis

\section{INTRODUCTION}

In the era of e-commerce and global competition, the scope of services from logistics service providers has increased manifold in developing country like India. Currently, logistics sector contributes around 14\% in GDP in India and will expect to grow at 1.5 to 2 times of the current GDP (Novonous, 2015-2020). Logistics Performance Index ranked India on 54th among 160 countries with a score of 3.08 (LPI Survey, 2014). It is very important for LSPs to maintain service quality of all logistics functions in order to survive and grow in the competitive world. LSPs have to meet the challenging role of delivering best quality services to their customers for their business continuity and future business (Liu and Xie, 2013).

In India, LSPs have ample opportunities to grow and expand their businesses due to increase in e-businesses and recent initiative of "MAKE IN INDIA" by Indian Government. Additionally, advancement in technology and rise in globalization can also be considered as responsible reasons for organizations to redesign their strategies and develop products to serve global needs through logistics service provider's capabilities. But logistics service providers are facing many challenges in order to fulfill the increased expectations of the organizations. The current capacities of LSPs are not synchronized with expected industry requirements.

In developing countries like India, infrastructural bottlenecks are one of the major concern areas to be improved on priority. The pathetic road conditions, inadequate roads, air and sea port capacities, poor connectivity, heavy congestion and traffic and issues at check posts and tolls etc. are few to name (Mitra, 2006). The national highways constitute only $2 \%$ of the Indian roads, but handling around $40 \%$ of the total freight movement by roadways. Five major airports and twelve major seaports in metro cities handling around $85 \%$ of the total freight traffic by airways. Lack of advanced and updated IT tools (Sauvage, 2003) and limited skilled workforce (Govindan et al., 2014) restricts the growth of LSPs also.

High investment and low margin due to untimely payment system by Indian shippers slows down the pace of logistics service providers. Moreover, the government policies and inspection strategies are not up to mark and can be considered as one of the important hurdle in the success story of LSPs (Rajesh et al., 2011). These obstacles sometimes become an important cause of failure of desired logistics services. 
The logistics sector in India is continuous to witness growth due to increase in retail, ecommerce and manufacturing sectors. Moreover, domestic and global consumption is rapidly increasing which opens many new opportunities for LSPs. To ensure smooth services from logistics service providers, the challenges need to be identified and removed. In this study, an attempt to identify and develop a structural relationship among challenges has been done. Then an appropriate framework for overcoming these challenges is also proposed. Therefore, the major objectives of this study are:

- To identify the challenges faced by logistics service providers for improving service quality.

- To develop a structural relationship framework for these challenges by Interpretive Structural Modeling (ISM) approach.

- To find driving power and dependence power and categorization of these factors into different categories by MICMAC analysis.

The remaining part of paper is organized as follows. In section 2, the literature review of challenges faced by logistics service providers is discussed. Section 3 deals with Interpretive Structural Modeling (ISM) methodology. Section 4 classifies the challenges on the basis of driving and dependence power, with the help of MICMAC Analysis and ISM model development in section 5. Section 6 includes discussion and finally conclusion in section 7 .

\section{LITERATURE REVIEW}

Traditionally, Delfmann et al. (2002) stated LSPs as "Companies which perform logistics activities on behalf of others" whereas Huo et al. (2008) revised the definition by stating LSPs as "a relationship between a shipper and a third party which, compared with the basic services, has more customized offerings, encompasses a broad number of service functions and is characterized by a long-term, more mutually beneficial relationship". Persson and Virum (2001) categorized LSPs strategically as third-party logistics operator, logistics integrator and logistics agents on the basis of their available physical assets. Additionally, Tezuka (2011) highlights the three characteristics of service provider as integrated, contract and consulting service providers.

The popularity of logistics outsourcing arises from number of reasons. The role of logistics service providers is very essential in conducting smooth flow of material and information in both upstream and downstream of supply chain (Kumar et al., 2012). Generally, Indian organizations outsource logistics activities to reduce cost, more focus on core competencies, better service quality and time saving. Currently, transportation is considered to be most crucial logistics activity which almost accounts for $50-60 \%$ followed by warehousing which accounts for another 25$30 \%$ of the total market, which is further followed by value added services and freight forwarding accounting for rest of the market as shown in Figure 1.

Various authors analyzed 3PL businesses, their categorization, structure and services on the basis of different types of industries they served (Marasco, 2008). Due to rise in recent market requirements, LSPs need to restructure their process in order to fulfill the enhanced customer expectations despite of so many challenges (Sahay and Mohan, 2006). In
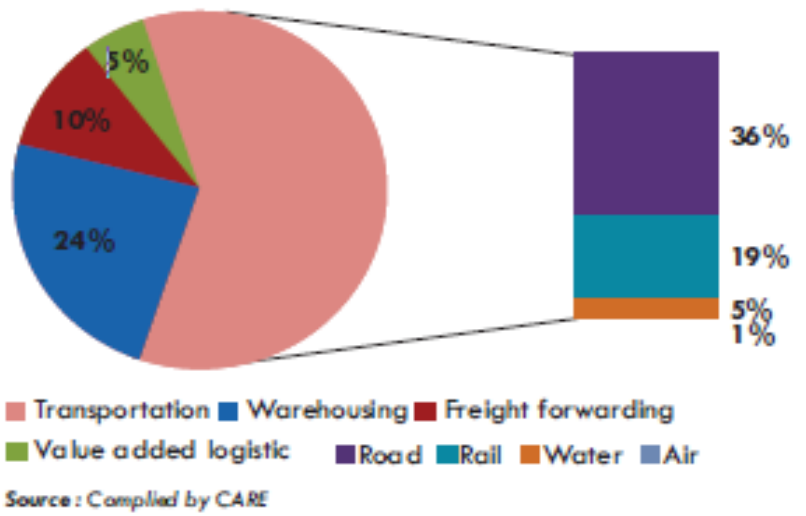

Figure 1 Distribution of logistics services in India

India being developing country; logistics sector is even not considered as an organized sector. Apart from infrastructure and shortage of skilled manpower, coordination among all supply chain stakeholders is an unavoidable barrier in delivering committed services (Bagchi and Larsen, 2003).

The use of IT in logistics sector is rapidly increasing but it is largely limited to the big size organizations. Chandra and Jain, 2009 have identified that the LSPs can adopt IT tools rather than conventional and manual methods of operations to improve their decision-making abilities across the entire supply chain and can reduce costs further. Javalgi and Todd (2004) emphasized on the importance of e-services across boundaries and creating value in the supply chains by reducing many other barriers. Restructuring of government policies on taxation and regulations also makes working conditions adverse (Chandra and Jain, 2009). In 2013, More and Basu have also identified the challenges related to supply chain finance which includes issues related to unpredictable cash-flows, lack of automation in the payment processes and lack of knowledge and training on supply chain.

So, there is need to identify and analyze the challenges faced by logistics service providers in delivering desired quality to the end customers. Based on literature review and experts' opinion, various challenges are identified and discussed in detail below.

1. Infrastructural Bottlenecks: For economic development and urbanization, logistics infrastructure is found to be critical enabler. Due to globalization, India is improving position in world trade channeling upsurge in transport volume (Venkatesh et al., 2017). The Indian government has already taken steps to expand and improve existing road and rail networks and modernizing harbors and airports (Mitra, 2013). But expansion of logistics infrastructure is not synchronized with the expected industry requirements. In developed countries, vehicles move around 800$1000 \mathrm{~km}$ in a day whereas, In India, it runs only 250$300 \mathrm{~km}$ a day (Sanyal, 2006b). This creates the major problem of mismatching of transport capacities as required as shown in Table 1. Pathetic condition of roads, poor connectivity, and high toll rates, corruption on highways and hinterlands and inadequate air and seaport capacities are the major infrastructural bottleneck (Sahay and Mohan, 2006). 
Table 1 Core infrastructural bottlenecks

\begin{tabular}{|c|c|c|}
\hline $\begin{array}{l}\text { Modes of } \\
\text { transport }\end{array}$ & Infrastructure & Key Constraints \\
\hline Road & $\begin{array}{l}\text { - Total road } \\
\text { network- over } \\
5,472,144 \mathrm{kms} \\
(3,400,233 \mathrm{mi}) \text { in } \\
2015 \\
\text { - National } \\
\text { highways include } \\
2 \% \text { of Indian } \\
\text { roads, they } \\
\text { handled } 40 \% \text { of } \\
\text { the traffic. }\end{array}$ & $\begin{array}{l}\text { - } \text { Bad condition of } \\
\text { roads } \\
\text { - Low average } \\
\text { speed(30- } \\
40 \mathrm{~km} / \mathrm{hr}) \\
\text { - Low Daily } \\
\text { average distance } \\
\text { travelled ( } 250 \\
\text { km) } \\
\text { - Issues at check- } \\
\text { post and toll-post }\end{array}$ \\
\hline Railways & $\begin{array}{l}\text { - Total Track } \\
\text { Length-119,630 } \\
\text { Kms }(74,330 \text { mi) } \\
\text { in } 2016\end{array}$ & $\begin{array}{l}\text { - Low service } \\
\text { guarantee } \\
\text { - No dedicated } \\
\text { freight corridors } \\
\text { - Low connectivity } \\
\text { to industry } \\
\text { - No fixed } \\
\text { schedule for } \\
\text { departure/arrival }\end{array}$ \\
\hline Airports & $\begin{array}{l}\text { - Domestic/lnterna } \\
\text { tional Airport- } \\
125 \\
\text { - } 5 \text { main metros } \\
\text { account for over } \\
85 \% \text { of total } \\
\text { freight traffic }\end{array}$ & $\begin{array}{l}\text { - Only major } \\
\text { airports has } \\
\text { infrastructure to } \\
\text { handle air cargo } \\
\text { - High Waiting } \\
\text { time } \\
\text { - Poor } \\
\text { warehousing } \\
\text { infrastructure }\end{array}$ \\
\hline Ports & $\begin{array}{l}\text { - Ports-212(Major } \\
12 \text { \& Minor 200) } \\
\text { - Capacity-Major } \\
\text { ports at } 500 \mathrm{~mm} \\
\text { MT and Minor } \\
\text { ports at } 230 \mathrm{mn} \\
\text { MT }\end{array}$ & $\begin{array}{l}\text { - Heavy } \\
\text { congestion at } \\
\text { ports } \\
\text { - Lack of good } \\
\text { connectivity with } \\
\text { roads } \\
\text { - Out-dated } \\
\text { equipment and } \\
\text { technology } \\
\text { - Low port } \\
\text { capacities and } \\
\text { number of berths }\end{array}$ \\
\hline
\end{tabular}

2. Lack of Efficient Technical System: GPS technology and tracking and tracing of shipments are already available advanced IT tools which are in process and used by shippers but there are around only $2 \%$ LSPs which follow these practices (Luisa et al., 2013). The country is continuously upgrading its resources technically but adoption rate is still very low. There is need to develop efficient technical systems and create awareness about importance of IT adoption to all the stakeholders for better economic development (Sauvage, 2003).

3. Inefficient Inspection Strategies: The customs and border authorities did not follow rigid guidelines and policies for inspection are not properly defined (Mitra,
2013; Rajesh et al., 2011). Multiple handling at checkposts leads to delay and damages to goods. Earlier, in India, the government levied various direct and indirect taxes on goods which makes their movement difficult within and across countries but after implementation of GST (Goods and Service Tax), things are expected to be better.

4. Lack of Government Support Policies: Logistics sector is not recognized as industry in India despite of 14 percent contribution towards GDP (Luthra et al., 2011). However, millions of employment opportunities are developed by this sector. Industries itself consider logistics as backbone and key driver to their economic and industrial growth. The governmental focus is still missing towards policy framework, development and recognition of logistics business as an industry (Govindan et al., 2014).

5. Fragmented and Unorganized Sector: Logistics sector in India is considered to be highly fragmented and unorganized business. It is an interplay of many small and large players where more than $90 \%$ of LSPs are those who own less than 2 trucks and $95 \%$ are those who own less than 5 trucks) impairs quality of services. (Mitra, 2006). Few large LSPs usually serve well established and known organizations with comparatively available resources than small players. On the other hand, small players ready to work for low margin which creates unavoidable obstacles for large ones (Ding et al., 2012).

6. Conventional Ways of Operations: In developing country, there is very slow adoption of automation due to unavailability and cost. The operations are majorly manual including loading and unloading of goods, warehousing, use of pallets and connecting with entire network (Mitra, 2006). More automation of operations can assist in creating nation-wide broadband logistics IT network and can fasten up all processes resulting in better customer satisfaction (Sharma et al., 2011).

7. Cost Implications: Logistics sector requires huge investment for resources like vehicles, skilled manpower and warehouses etc. Logistics is a high cost and low-margin business (Mitra, 2013). The untimely payment pattern by Indian shippers creates shortage of adequate working capital for LSPs. Poor physical and communications infrastructure is another deterrent to attracting investments in the logistics sector. High costs of operation and delays involved in compliances with varying documentation requirements make the business unattractive (More and Basu, 2013; Govindan et al., 2014).

8. Lack of appropriate performance metrics: No performance standards or benchmarks have been defined by Indian government to regulate the logistics sector (Mitra, 2013). Hundreds of logistics service providers resources are not up to mark and providing services with inadequate resources. There is no appropriate performance metrics are defined for establishment and selection of service provider (Rajesh et al., 2011). This can be considered a big bottleneck which is affecting the logistics service.

9. Shortages of Skilled Workforce: In India, due to less importance to logistics sector, the emphasis on 
specialized training, education and technical knowledge of employees in logistics business is also missing (Govindan et al., 2014). Although this sector contributes very high in GDP, but unavailability of skilled manpower for delivering desired logistics services is a big barrier (Thai et al. 2011; Abdulrahman et al., 2014).

10.Less awareness towards sustainability measures: Unawareness of LSPs towards sustainability is an important factor leads in low implementation of sustainable practices (Abbasi and Nilsson, 2016; Colicchia et al., 2013). Very few LSPs in India shows concern towards environment and use reusable and recyclable pallets, eco-friendly vehicles and green processes in their operations. Still, there is need to create awareness so that many more can start adopting sustainable practices and make optimum use of available resources.

Earlier, few challenges like "Complex State Documentation" and "Lack of coordination with clients" are considered to be very important for LSPs but after implementation of Goods and Service Tax (GST) in India, these barriers are automatically vanished to a large extent. All the above discussed challenges are clubbed and shown in Figure 2.

\section{ISM METHODOLOGY AND MODEL DEVELOPMENT}

Interpretive Structural Modeling(ISM), was first proposed by J. Warfield in 1974, a computer assisted methodology that helps in dealing with complex issues by identifying the relations between variables involved in complex issues/problems under study. It helps in better understanding the fundamentals of any complex problem/situation, as well as to put together a course of action for solving it.

ISM can act as a tool for imposing order and direction on the complexity of relationships among elements of a system (Sage, 1977). It is Interpretive as it enables individuals or groups to develop mapping/relationships between variables of the complex system. It is structural as it simplifies the complex structure into simple modules, on the basis of relationship. It is a modeling technique as it portrays overall structure and specific relationships in carefully designed patterns employing graphics as well as words.

In this paper, there is an attempt to understand the relationship between different challenges so that these challenges can be rectified for the betterment of service quality of LSPs. So, ISM helps to understand the direct and indirect relationships between the factors to describe the situation more accurately than the individual factor (Jharkharia and Shankar, 2007). ISM assists decision makers to decide by taking collective understanding of these relationships into consideration. Moreover, it produces a structural representation of the original problem situation in form of digraph that makes communication more effective to others. The ISM approach is found to be very systematic and efficient. All these advantages of ISM over other methods make it is more suitable for the problem under hand.

The applications of ISM methodology are not limited to specific fields. It has been widely used by many researchers in different areas. Singh et al. (2008) applied the ISM methodology to the field of knowledge management to understand the relationship among barriers in implementing knowledge management. Mandal and Deshmukh (1994) have employed ISM methodology in vendor selection process and identified the key variables using direct and indirect relationships amongst the variables. Some more instances where ISM methodology applied are: Supply chain sustainability (Faisal, 2010), Supply chain agility (Agarwal et al., 2007), Competitiveness of SMEs (Singh et al., 2007b), IT enablement of supply chain (Jharkharia et al., 2005), Reverse Logistics (Ravi et al., 2005) and many other fields. The various steps for ISM are shown in Table 2.

\subsection{Structural Self Interaction Matrix (SSIM)}

For analyzing the challenges in developing SSIM, the following four symbols have been used to denote the direction of relationship between variables ( $i$ and $j$ ). Vvariable $\mathrm{i}$ will lead to variable $\mathrm{j}$; A-Variable $\mathrm{j}$ will lead to Variable i; X-Variable i and j will lead to each other; $\mathrm{O}-$ Variable $\mathrm{i}$ and $\mathrm{j}$ are unrelated.

The inputs for developing SSIM among all the identified challenges as shown in figure1 have been taken from four experts from Indian logistics sector. All the experts are from middle and top management working in well-known logistics companies of India. Expert 1 is the head Logistics with experience of 18 years, Expert 2 is the manager in operations department with experience of 10 years, Expert 3 is the senior manager in supply chain department with 12 years of experience and Expert- 4 is the assistant manager of operations department with 7 years of experience, all are working in different but wellestablished logistics companies of India. The companies of name cannot be disclosed due to confidential reasons. They were consulted in identifying the nature of contextual relationships among the challenges to understand the real issues of the industry. They relate each challenge with other challenges and establish relationships in terms of $\mathrm{V}$, $\mathrm{A}, \mathrm{X}$ and $\mathrm{O}$ as shown in Table 3 .

\subsection{Reachability Matrix}

Initial Reachability matrix (Binary matrix) can made by converting SSIM Matrix into binary form as shown in Table 4, by substituting $\mathrm{V}, \mathrm{A}, \mathrm{X}$ and $\mathrm{O}$ by 1 or 0 as per given case. The substitution of $1 \mathrm{~s}$ and $0 \mathrm{~s}$ are as per the following rules:

If $(i, j)$ value in SSIM is $V$ then $(i, j)$ value in the reachability matrix will be 1 and $(\mathrm{j}, \mathrm{i})$ value will be 0 ;

If $(i, j)$ value in SSIM is A then $(i, j)$ value in the reachability matrix will be 0 and $(\mathrm{j}, \mathrm{i})$ value will be 1 ;

If $(i, j)$ value in SSIM is $X$ then $(i, j)$ value in the reachability matrix will be 1 and $(\mathrm{j}, \mathrm{i})$ value will be 1 ;

If $(i, j)$ value in SSIM is 0 then $(i, j)$ value in the reachability matrix will be 0 and $(\mathrm{j}, \mathrm{i})$ value will be 0 ; 


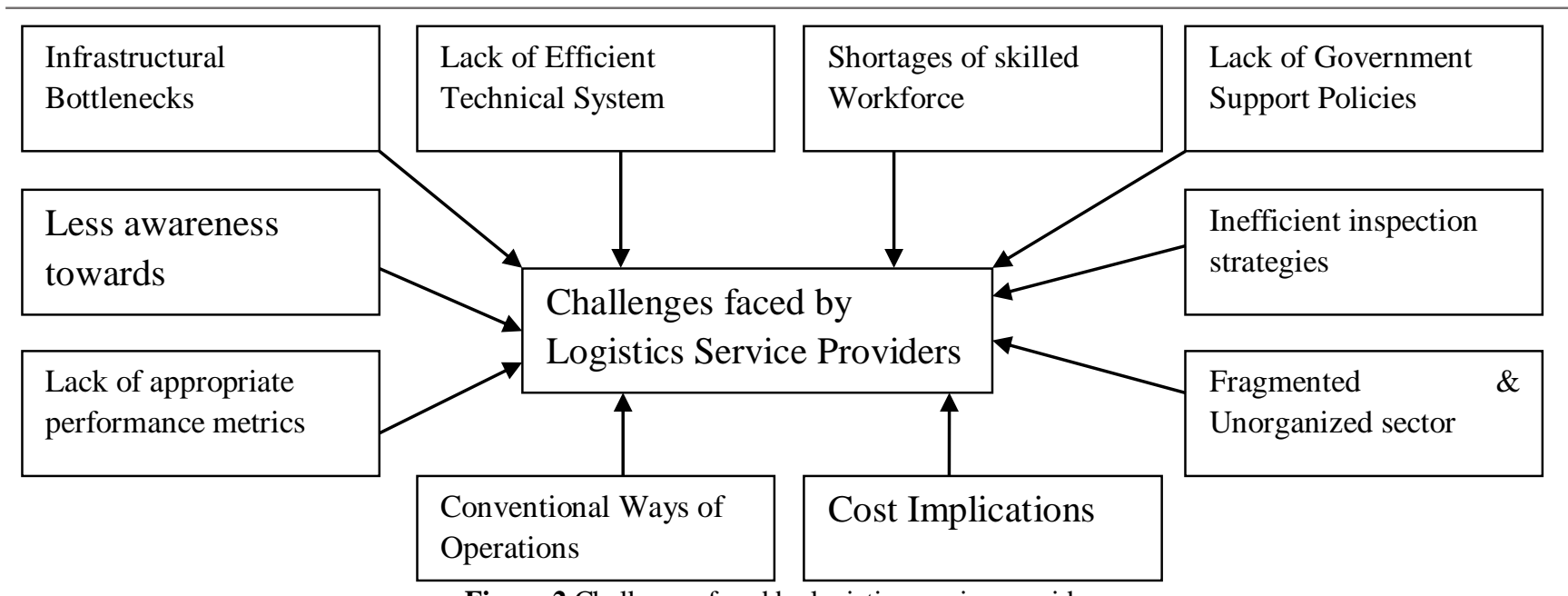

Figure 2 Challenges faced by logistics service providers

Table 2 Steps for ISM (Warfield, 1974)

\begin{tabular}{|c|c|}
\hline S.No & Steps for Interpretive Structural Modelling (ISM) \\
\hline 1. & Identify barriers from the problem under study. \\
\hline 2. & Develop contextual relationship among barriers by taking inputs from experts. \\
\hline 3. & $\begin{array}{l}\text { Build Structural Self-Interaction Matrix (SSIM) for the barriers based on symbols } \\
\text { (discussed below). }\end{array}$ \\
\hline 4. & $\begin{array}{l}\text { Develop Reachability matrix from SSIM matrix and check for transitivity of } \\
\text { matrix. } \\
\text { (Transitivity: A-> B; B-> C then A-> C) }\end{array}$ \\
\hline 5. & Partition of Reachability matrix into different levels. \\
\hline 6. & Diagraph is developed and transitive links are removed from Reachability matrix. \\
\hline 7. & $\begin{array}{l}\text { Convert diagraph into ISM based model by replacing variables nodes with } \\
\text { statements. }\end{array}$ \\
\hline 8. & $\begin{array}{l}\text { Review the ISM model and check for any conceptual inconsistency or if required } \\
\text { make necessary changes. }\end{array}$ \\
\hline
\end{tabular}

Table 3 Structural self-interaction matrix (SSIM)

\begin{tabular}{|c|c|c|c|c|c|c|c|c|c|c|c|}
\hline No & Challenges & 10 & 9 & 8 & 7 & 6 & 5 & 4 & 3 & 2 & 1 \\
\hline 1 & $\begin{array}{l}\text { Infrastructural } \\
\text { Bottlenecks }\end{array}$ & V & V & V & V & V & A & 0 & 0 & V & \\
\hline 2 & $\begin{array}{l}\text { Lack of Efficient } \\
\text { Technical } \\
\text { Systems }\end{array}$ & 0 & V & V & A & V & 0 & $x$ & V & & \\
\hline 3 & $\begin{array}{l}\text { Inefficient } \\
\text { Inspection } \\
\text { Strategies }\end{array}$ & 0 & 0 & $A$ & A & $X$ & A & 0 & & & \\
\hline 4 & $\begin{array}{l}\text { Lack of } \\
\text { Government } \\
\text { support Policies }\end{array}$ & V & V & V & $x$ & V & $X$ & & & & \\
\hline 5 & $\begin{array}{l}\text { Fragmented \& } \\
\text { Unorganized } \\
\text { Sector }\end{array}$ & 0 & V & V & $x$ & V & & & & & \\
\hline 6 & $\begin{array}{l}\text { Conventional } \\
\text { Ways } \\
\text { Operations }\end{array}$ & 0 & A & $A$ & $\mathrm{X}$ & & & & & & \\
\hline 7 & Cost Implications & 0 & V & V & & & & & & & \\
\hline
\end{tabular}


Gupta et al.: Analysis of Challenges Faced by Indian Logistics Service Provider

\begin{tabular}{|c|c|c|c|c|c|c|c|c|c|c|c|}
\hline No & Challenges & 10 & 9 & 8 & 7 & 6 & 5 & 4 & 3 & 2 & 1 \\
\hline 8 & $\begin{array}{l}\text { Lack of } \\
\text { Appropriate } \\
\text { Performance } \\
\text { Metrics }\end{array}$ & V & $x$ & & & & & & & & \\
\hline 9 & $\begin{array}{l}\text { Shortages of } \\
\text { Skilled Workforce }\end{array}$ & 0 & & & & & & & & & \\
\hline 10 & $\begin{array}{l}\text { Unawareness } \\
\text { towards } \\
\text { Sustainable } \\
\text { Practices }\end{array}$ & & & & & & & & & & \\
\hline
\end{tabular}

Table 4 Final reachability matrix

\begin{tabular}{|c|c|c|c|c|c|c|c|c|c|c|c|c|}
\hline No & Challenges & 1 & 2 & 3 & 4 & 5 & 6 & 7 & 8 & 9 & 10 & $\begin{array}{l}\text { Driving } \\
\text { Power }\end{array}$ \\
\hline 1 & $\begin{array}{l}\text { Infrastructural } \\
\text { Bottlenecks }\end{array}$ & 1 & 1 & 0 & 0 & 0 & 1 & 1 & 1 & 1 & 1 & 7 \\
\hline 2 & $\begin{array}{l}\text { Lack of efficient } \\
\text { Technical } \\
\text { Systems }\end{array}$ & 0 & 1 & 1 & 1 & 0 & 1 & 0 & 1 & 1 & 0 & 6 \\
\hline 3 & $\begin{array}{l}\text { Inefficient } \\
\text { Inspection } \\
\text { Strategies }\end{array}$ & 0 & 0 & 1 & 0 & 0 & 1 & 0 & 0 & 0 & 0 & 2 \\
\hline 4 & $\begin{array}{l}\text { Lack of } \\
\text { Government } \\
\text { support Policies }\end{array}$ & 0 & 1 & 0 & 1 & 1 & 1 & 1 & 1 & 1 & 1 & 8 \\
\hline 5 & $\begin{array}{l}\text { Fragmented \& } \\
\text { Unorganized } \\
\text { Sector }\end{array}$ & 1 & 0 & 1 & 1 & 1 & 1 & 1 & 1 & 1 & 0 & 8 \\
\hline 6 & $\begin{array}{l}\text { Conventional } \\
\text { Ways of } \\
\text { Operations }\end{array}$ & 0 & 0 & 1 & 0 & 0 & 1 & 1 & 0 & 0 & 0 & 3 \\
\hline 7 & Cost Implications & 1 & 1 & 1 & 1 & 1 & 1 & 1 & 1 & 1 & 0 & 9 \\
\hline 8 & $\begin{array}{l}\text { Lack of } \\
\text { appropriate } \\
\text { performance } \\
\text { metrics }\end{array}$ & 0 & 0 & 1 & 0 & 1 & 1 & 1 & 1 & 1 & 1 & 7 \\
\hline 9 & $\begin{array}{l}\text { Shortages of } \\
\text { Skilled Workforce }\end{array}$ & 0 & 0 & 0 & 0 & 1 & 1 & 1 & 1 & 1 & 0 & 5 \\
\hline 10 & $\begin{array}{l}\text { Unawareness } \\
\text { towards } \\
\text { sustainable } \\
\text { practices }\end{array}$ & 0 & 0 & 0 & 0 & 0 & 0 & 0 & 0 & 0 & 1 & 1 \\
\hline & $\begin{array}{l}\text { Dependence } \\
\text { Power }\end{array}$ & 3 & 4 & 6 & 4 & 5 & 9 & 7 & 7 & 7 & 4 & \\
\hline
\end{tabular}

There is also need to check for transitivity. It is checked for all possible transitive links and all revisions done are mentioned in Table 4. The driving power and dependence power of each challenge is calculated. Driving power explains the influencing power of a particular factor with respect to other factors whereas dependence power reflects the dependency of one factor on other factors. The driving power for each challenge is calculated by adding the horizontal sum of all values on the basis of relationship with other challenges whereas dependence power for each challenge is the vertical sum of that individual challenge with respect to other challenges (Attri et al., 2013).

\subsection{Level Partitions}

From the final reachability matrix, the reachability and antecedent set for each challenge. The reachability set is a set of variables (including itself) which it may help achieve whereas antecedent set is a set of variables (including itself) which may help achieving it. Thereafter, intersection of these sets is derived for all challenges. The challenges for which the reachability and the intersection sets are same, they occupy the top most level in the hierarchy of ISM model. Once the top most layer is identified, it is separated out from the other variables. Then, the same process will be repeated to find out variables in the next level (as shown in table 5-9). The process is continued till the level of each variable is identified (as shown in table 10). These levels help in building the digraph and ISM model.

Here, as from Table 5, the first leveling of challenges can be done. The challenges 3, 6 and 10 are the challenges with weak driving and weak dependence power as shown in table 4 . These challenges are not found to be very critical for LSPs.

From Table 6, challenges 8 and 9 are found to be at second level. These are dependent challenges with high dependence power and slow driving power. They usually depend on other challenges so they do not create big hurdles for LSPs. 

Operations and Supply Chain Management 11(4) pp. 214 - 225 () 2018

Table 5 Level partitions: Iteration-I

\begin{tabular}{|c|l|l|l|l|}
\hline $\begin{array}{c}\text { Challenge } \\
\text { Number }\end{array}$ & Reachability Set & Antecedent Set & Intersection & Level \\
\hline 1 & $1,2,6,7,8,9,10$ & $1,4,5$ & 1 & \\
\hline 2 & $2,3,4,6,8,9$ & $1,2,4,7$ & 2,4 & I \\
\hline 3 & 3,6 & $2,3,5,6,7,8$ & 3,6 & \\
\hline 4 & $2,4,5,6,7,8,9,10$ & $2,4,5,7$ & $2,4,5,7$ & \\
\hline 5 & $1,3,4,5,6,7,8,9$ & $3,4,5,7,8,9$ & $4,5,7,8,9$ & \\
\hline 6 & $3,6,7$ & $1,2,3,4,5,6,7,8,9$ & $3,6,7$ & \\
\hline 7 & $1,2,3,4,5,6,7,8,9$ & $1,4,5,6,7,8,9$ & $1,4,5,6,7,8,9$ & \\
\hline 8 & $3,5,6,7,8,9,10$ & $1,2,4,5,7,8,9$ & $5,7,8,9$ & \\
\hline 9 & $5,6,7,8,9$ & $1,2,4,5,7,8,9$ & $5,7,8,9$ & \\
\hline 10 & 10 & $1,4,8,10$ & 10 & \\
\hline
\end{tabular}

Table 6 Level partitions: Iteration-II

\begin{tabular}{|c|l|l|l|l|}
\hline $\begin{array}{c}\text { Challenge } \\
\text { Number }\end{array}$ & \multicolumn{1}{|c|}{ Reachability Set } & Antecedent Set & Intersection & Level \\
\hline 1 & $1,2,8,9$ & $1,4,5$ & 1 & \\
\hline 2 & $2,4,8,9$ & $1,2,4$ & 2,4 & \\
\hline 4 & $2,4,5,8,9$ & $2,4,5$ & $2,4,5$ & \\
\hline 5 & $1,3,4,5,8,9$ & $3,4,5,8,9$ & $3,4,5,8,9$ & \\
\hline 7 & $1,2,4,5,8,9$ & $1,4,5,8,9$ & $1,4,5,8,9$ & \\
\hline 8 & $5,8,9$ & $1,2,4,5,8,9$ & $5,8,9$ & II \\
\hline 9 & $5,8,9$ & $1,2,4,5,8,9$ & $5,8,9$ & II \\
\hline
\end{tabular}

Table 7 Level Partitions: Iteration-III

\begin{tabular}{|c|c|c|c|c|}
\hline $\begin{array}{c}\text { Challenge } \\
\text { Number }\end{array}$ & Reachability Set & Antecedent Set & Intersection & Level \\
\hline 1 & 1,2 & 1,4 & 1 & III \\
\hline 2 & 2,4 & $1,2,4$ & 2,4 & III \\
\hline 4 & 2,4 & 2,4 & 3,4 & \\
\hline 5 & $1,3,4$ & 3,4 & 1,4 & \\
\hline 7 & $1,2,4$ & 1,4 & & \\
\hline
\end{tabular}

Table 8 Level Partitions: Iteration-IV

\begin{tabular}{|c|c|c|c|c|}
\hline $\begin{array}{c}\text { Challenge } \\
\text { Number }\end{array}$ & Reachability Set & Antecedent Set & Intersection & Level \\
\hline 1 & 1 & 1 & 1 & IV \\
\hline 5 & 1,3 & 3 & 1 & IV \\
\hline 7 & 1 & 1 & 3 & \\
\hline
\end{tabular}

Table 9 Level Partitions: Iteration-V

\begin{tabular}{|c|c|c|c|c|}
\hline $\begin{array}{c}\text { Challenge } \\
\text { Number }\end{array}$ & Reachability Set & Antecedent Set & Intersection & Level \\
\hline 5 & 3 & 3 & 3 & V \\
\hline
\end{tabular}


Gupta et al.: Analysis of Challenges Faced by Indian Logistics Service Provider

Operations and Supply Chain Management 11(4) pp. 214 - 225 () 2018

Table 10 Levels of all LSPs Challenges

\begin{tabular}{|c|c|c|c|c|}
\hline $\begin{array}{c}\text { Challenge } \\
\text { Number }\end{array}$ & Reachability Set & Antecedent Set & Intersection & Level \\
\hline 1 & 1 & 1 & 1 & IV \\
\hline 2 & 2,4 & $1,2,4$ & 2,4 & III \\
\hline 3 & 3,6 & $2,3,5,6,7,8$ & 3,6 & I \\
\hline 4 & 2,4 & 2,4 & 2,4 & III \\
\hline 5 & 3 & 3 & 3 & V \\
\hline 6 & $3,6,7$ & $1,2,3,4,5,6,7,8,9$ & $3,6,7$ & I \\
\hline 7 & 1 & 1 & 1 & IV \\
\hline 8 & $5,8,9$ & $1,2,4,5,8,9$ & $5,8,9$ & II \\
\hline 9 & $5,8,9$ & $1,2,4,5,8,9$ & $5,8,9$ & I \\
\hline 10 & 10 & $1,4,8,10$ & 10 & \\
\hline
\end{tabular}

Challenges 2 and 4 have reached to level 3 in Table 7. They have high driving power and less dependence power. These barriers are critical to LSPs as their presence act as an obstacle to bring success to LSPs.

In Table 8, challenges 1 and 7 have reached to level 4. They are coming as linkage variables which show they are linked with other challenges. If these challenges are rectified, the other challenges will also get improved.

Challenge 5 is found to be at fifth level. This is the most crucial challenge to LSPs. The interplay of small and large logistics players makes logistics sector highly fragmented and unorganized sector in India. The LSPs need to rectify this challenge with most priority.

\section{CLASSIFICATION OF CHALLENGES}

The MICMAC analysis assists in development of graphs to classify LSPs challenges on the basis of their driving and dependence power. They are classified into four categories as autonomous variables, dependent variables, linkage variables and independent variables. These classifications of variables are similar to classifications used by Mandal and Deshmukh (1994).

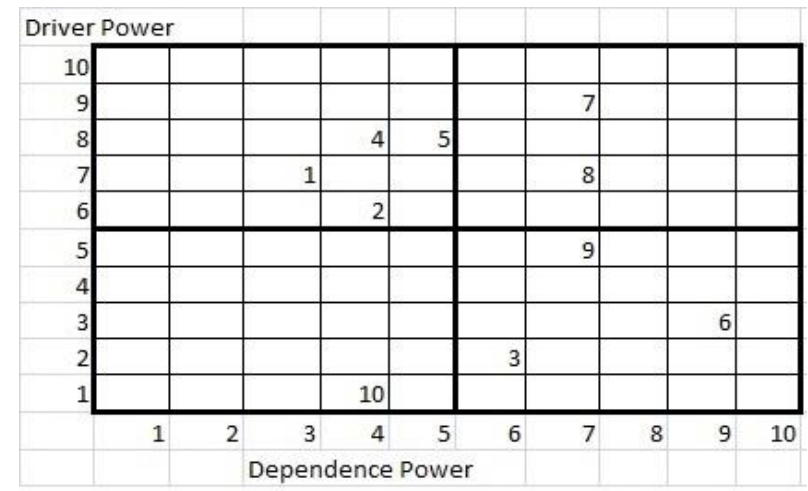

Figure 3 Cluster of LSPs challenges

In the classification of challenges, the first cluster is autonomous variables that have weak driving power and weak dependence power. The autonomous variables are relatively disconnected from the system (Challenges like 10 from Figure 3). The second cluster is dependent variables which have weak driving power and high dependence power (Challenges like 3, 6 and 9 from Figure 3). The third cluster consist of linkage variables which has high driving power and high dependence power. These challenges have high links with other challenges and also a feedback effect on themselves (Challenges like 7, 8 from Figure 3) (Singh et al., 2008). The fourth cluster is driver variables which has high driving power and low dependence power (Challenges like 1, 2, 4 and 5 from Figure 3).

\section{FORMATION OF ISM MODEL}

The structural model is generated from final reachability matrix (Table 4). The relationship between the challenges i \& j are presented by an arrow which points from $\mathrm{i}$ to $\mathrm{j}$. This graph is called as an initial directed graph or diagraph. After removing the transitivity, the ISM based model is shown in Figure 4.

\section{DISCUSSION}

It is important to understand the levels of LSPs challenges for providing effective service quality to their customers. "Unawareness towards sustainable practices", "Conventional ways of operations" and "Inefficient Inspection strategies" is occurring at the top level of the structural ISM model. "Unawareness towards sustainable practices" is an autonomous variable which has weak driving and dependence power and remains disconnected from the system as shown in figure 3. Due to huge blend of small and large players in logistics sector, the concern towards sustainable practices is not taken as priority (Luthra et al., 2011) which is at same pace in other countries as well (Abdulrahman et al., 2014). In Indian scenario, the logistics sector has not defined any benchmarks for logistical activities which in turn, enhance the conventional ways of operations handling and ineffective planning and implementation of inspection strategies. 


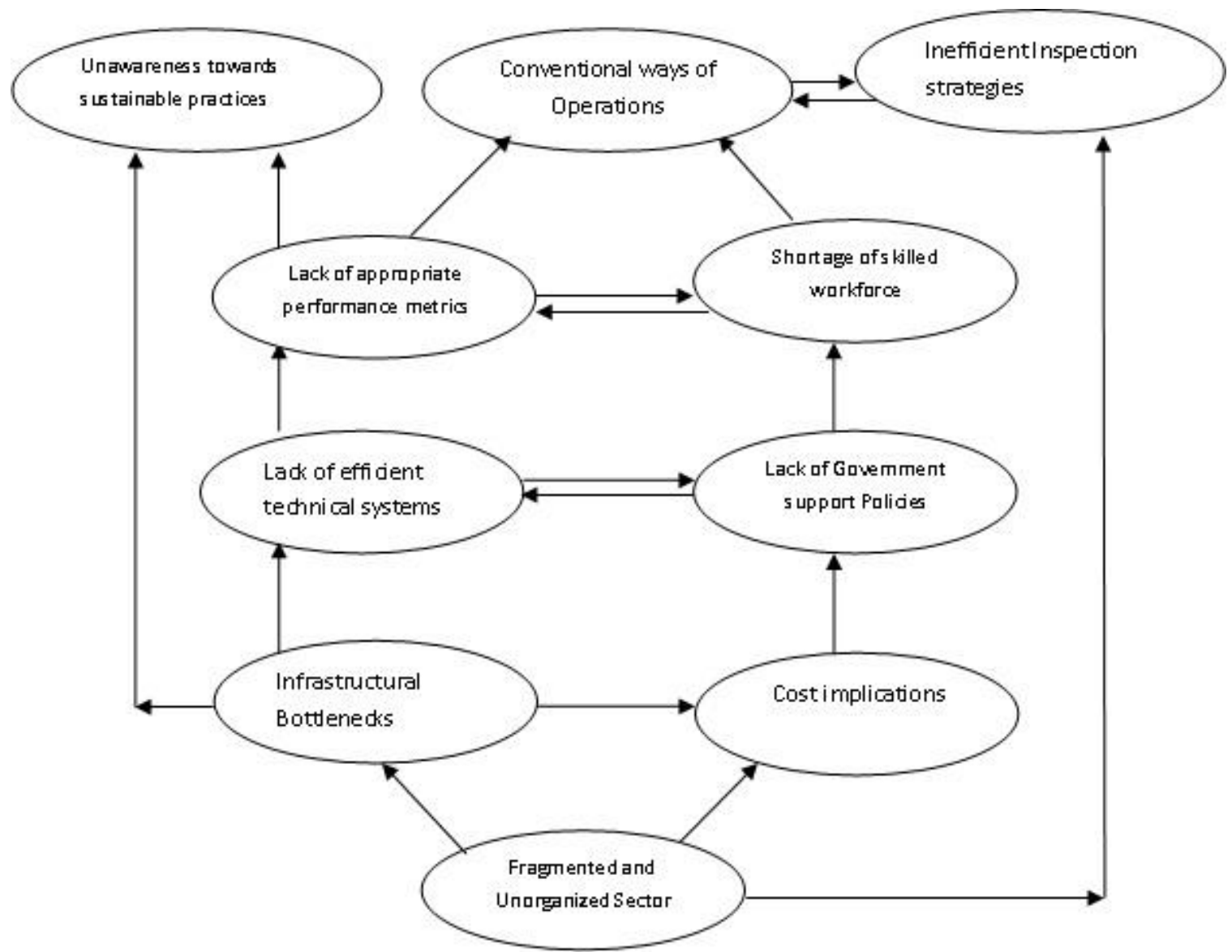

Figure 4 ISM based model

They are more of dependent variables which will automatically rectify when strict internal and external auditing compliances will be defined. Therefore, the top most challenges are not of too much importance. "Lack of appropriate performance metrics" and "Shortage of skilled workforce" are positioned at the second level in the hierarchy. In India, shortage of skilled workforce does not create major hurdles due to their high dependency on other challenges like lack of government policies and fragmented and unorganized sector etc. The same problems are also faced by Australian logistics companies (Thai et al., 2011). Despite of very high contribution to GDP, unlike engineering or manufacturing sector, there is hardly any focus on training, education and technical knowledge of employees (Mitra, 2013). A challenge like lack of appropriate performance metrics shows the requirement to strengthen the performance measurement processes and improve the level of quality of services delivered. "Lack of Efficient Technical Systems" and "lack of Government support policies" is coming at third level of ISM model. The Government need to emphasis more on these challenges and can enhance the level of logistics service quality. In India, due to high fragmentation, LSPs are less adopted to digitalization and automation which results in conventional ways of operations and manual process handling.

"Infrastructural Bottlenecks" and "Cost Implications" are coming at the fourth level of hierarchy. Infrastructural issues like pathetic road conditions, slow toll transactions, lack of integration in transport networks etc. are the main critical hurdles in the Indian context. Although, the Government is coming up with many initiatives like Goods and Service Tax (GST), Make in INDIA, and increased use of eco-friendly and green products so, we can expect things will be better in near future and these challenges can be rectified. "Cost implications" are basically limitations on investments made by LSPs on various resources. "Cost implications" is coming to be as linking variable which have high links with other variables and also a feedback effect on themselves (Singh et al. 2007a). These challenges need to deal with utmost care and rectify them for betterment. "Fragmented and Unorganized Sector" is at the fifth level of ISM model are driver or independent variables. They have high driving power and low dependence power which drives all other challenges and removal of these challenges will help in improving service quality of logistics service providers. Due to high fragmentation, many small and large LSPs catering different customer segments, are just providing solutions to logistics issues but not something, which is appreciable for the growth of the economy. In countries like Malaysia and China, fragmentation of the sector is found to be complex issue and need attention (Ali et al. 2008). This is the most crucial barriers which have to be removed on the top priority. 


\section{CONCLUSION AND FUTURE SCOPE}

The ten challenges faced by logistics service providers in delivering effective service quality are identified from literature review and expert opinion. The challenges are clubbed into different clusters by ISM methodology for in-depth understanding about the nature and impact of each challenge on LSPs services. From the study it is observed that the fragmented and unorganized sector, infrastructural bottlenecks and cost implications are the most crucial challenges which are faced by Indian service providers. After the implementation of GST in India, transparency in system has increased due to collaboration among large and small logistics service providers for utilizing common resources. Although the Government has initiated various projects like Dedicated Freight Corridors (DFC), Inland Water Ways (Coastal line shipping) etc. and many infrastructures related mega projects to overcome these hurdles but still logistic service providers are struggling to provide service quality as per dynamic needs of customers. LSPs also face hurdles in making huge investments in procuring and maintaining resources.

Lack of efficient technical system is found to be a driver variable which affects other challenges as well. LSPs prefer to work out in their own conventional way of operations due to non-availability of updated technology. There is need of availability of technical systems and updated technology adoption for smooth coordination and communication among customers and logistics service providers. The Government is also encouraging manpower to learn and upgrade their skills by associated with many programs like Pradhanmantri Kaushal Vikas Yojna etc. The Government has started taking steps in the direction of improvement but still a long way to go to meet the exact requirements. Lack of performance metrics is a linking variable which links all the other challenges. So, there is huge requirement of defining and establishing strict performance measures to streamline and improve the quality of services delivered. Unawareness of sustainability practices is found to be disconnected from the system. Currently, logistics service providers are not actively contributing in sustainable practices but it is the need of hour to make optimum utilization of scarce resources. Now, in this research, the relationship between challenges is retrieved using ISM methodology but the results are not checked and validate statistically. To make it statistically valid, a technique, SEM (Structured Equation Modeling), referred as linear structural relationship approach, can be used.

\section{ACKNOWLEDGEMENT}

Authors would like to express their sincere thanks to reviewers and editor of the journal for valuable suggestions and contents of the paper.

\section{REFERENCES}

Abbasi, M. and Nilsson, F. (2016). Developing environmentally sustainable logistics: Exploring themes and challenges from a logistics service providers' perspective. Transportation Research Part D: Transport and Environment, 46, pp. 273-283.

Abdulrahman, M. D., Gunasekaran, A., and Subramanian, N. (2014). Critical barriers in implementing reverse logistics in the Chinese manufacturing sectors. International Journal of Production Economics, 147, pp. 460-471.

Agarwal, A., Shankar, R., \& Tiwari, M. K. (2007). Modeling agility of supply chain. Industrial Marketing Management, 36(4), 443-457.

Ali, R. M., Jaafar, H. S., and Mohamad, S. (2008). Logistics and supply chain in Malaysia: Issues and challenges. In EASTS International Symposium Transportation incorporating Malaysian Universities Transport Research Forum Conference 2008 (MUTRFCO8), Universiti Teknologi Malaysia (1213).

Attri, R., Dev, N., and Sharma, V. (2013). Interpretive structural modeling (ISM) approach: an overview. Research Journal of Management Sciences, 2319, pp. 1171.

Bagchi, K. P. and Skjoett-Larsen, T. (2003). Integration of Information Technology and Organizations in a Supply Chain. The International Journal of Logistics Management, 14(1), pp. 89-108.

Chandra, P., and Jain, N. (2009). The logistics sector in India: Overview and challenges in Indian Economic Superpower: Fiction or Future? World Scientific Press, Singapore, pp. 105-134.

Colicchia, C., Marchet, G., Melacini, M. and Perotti, S. (2013). Building environmental sustainability: empirical evidence from Logistics Service Providers. Journal of Cleaner Production, 59, pp. 197-209.

Delfmann, W., Albers, S., and Gehring, M. (2002). The impact of electronic commerce on logistics service providers. International Journal of Physical Distribution \& Logistics Management, 32(3), pp. 203-222.

Ding, M.J., Kam, B. H., and Lalwani, C.S. (2012). Operational routines and supply chain competencies of Chinese logistics service providers. The International Journal of Logistics Management, 23(3), pp. 383-407.

Faisal, M.N. (2010). Sustainable Supply chains: a study of interaction among the enablers. Business Process management Journal, 16(3), pp. 508-529.

Govindan, K., Kaliyan, M., Kannan, D., and Haq, A. N. (2014). Barriers analysis for green supply chain management implementation in Indian industries using analytic hierarchy process. International Journal of Production Economics, 147, pp. 555-568.

Harland, C.M., Caldwell, N.D., Powell, P. and Zheng, J. (2007). Barriers to supply chain information integration: SMEs adrift of eLands. Journal of Operations Management, 25(6), pp. 1234-1254.

Huo, H., and Wei, Z. (2008). Grey Multi-Hierarchical Evaluation of Third Party Logistics Providers in the Environment of Supply Chain. 4th International Conference on Wireless Communications, Networking and Mobile Computing, 2008. WiCOM'08, pp. 1-4, IEEE.

Javalgi, R. G., Martin, C. L., and Todd, P. R. (2004). The 
export of e-services in the age of technology transformation: challenges and implications for international service providers. Journal of Services Marketing, 18(7), pp. 560-573.

Jharkharia S. and Shankar R. (2005). IT-enablement of supply chains: understanding the barriers. The Journal of Enterprise Information Management, 18(1), pp. 11-27.

Jharkharia, S., and Shankar, R. (2007). Selection of logistics service provider: An analytic network process (ANP) approach. Omega, 35(3), pp. 274-289.

Kumar, P. and Singh, R. K. (2012). A fuzzy AHP and TOPSIS methodology to evaluate 3PL in a supply chain. Journal of Modeling in Management, 7(3), pp. 287-303.

Liu, W. H., and Xie, D. (2013). Quality decision of the logistics service supply chain with service quality guarantee. International Journal of Production Research, 51(5), pp. 1618-1634.

LPI Survey, World Bank (2014), http://lpi.worldbank.org/international/global/2014 accessed on 10.7.2015.

Luisa, C., Vieira, S., Coelho, A.S., Maria, M. and Luna, M. (2013). ICT implementation process model for logistics service providers. Industrial Management \& Data Systems, 113(4), pp. 484-505.

Luthra, S., Kumar, V., Kumar, S., and Haleem, A. (2011). Barriers to implement green supply chain management in automobile industry using interpretive structural modeling technique: An Indian perspective. Journal of Industrial Engineering and Management, 4(2), pp. 231-257.

Mandal, A. and Deshmukh S.G. (1994). Vendor Selection using Interpretive Structural Modelling ISM. International Journal of Operations and Production Management, 14(6), pp. 52-59.

Marasco, A. (2008). Third-party logistics: A literature review. International Journal of Production Economics, 113(1), pp. 127-147.

Manda, S. (2012). Strategic Analysis of logistics spend and outsourcing trends in India. Frost \& Sullivan Market Research, 29 June, 2012. (www.frost.com) accessed on 18.01.2015.

Mitra, S. (2006). A survey of third-party logistics (3PL) service providers in India. IIMB Management Review, 18(2), pp. 159-174.

Mitra, S. (2013). The 2008 Survey of Indian Third-Party Logistics (3PL) Service Providers: Comparisons with the 2004 Survey. Technological Solutions for Modern Logistics and Supply Chain Management, 129.

More, D. and Basu, P., (2013). Challenges of supply chain finance: A detailed study and a hierarchical model based on the experiences of an Indian firm. Business Process Management Journal, 19(4), pp. 624-647.

Novonous: Intelligence Redefined. Logistics Market in India 2015 - 2020 published on 19 May 2016.

Persson, G., and Virum, H. (2001). Growth strategies for logistics service providers: a case study. The
International Journal of Logistics Management, 12(1), pp. 53-64.

Rajesh, R., Pugazhendhi, S., Ganesh, K., Muralidharan, C. and Sathiamoorthy, R. (2011). Influence of 3Pl service offerings on client performance in India. Transportation Research Part E: Logistics and Transportation Review, 47(2), pp. 149-165.

Ravi, V., and Shankar, R. (2005). Analysis of interactions among the barriers of reverse logistics. Technological Forecasting and Social Change, 72(8), pp. 10111029.

Sage A.P. (1997). Interpretive structural modeling: Methodology for large scale systems. New York, NY: McGraw-Hill.

Sahay, B. S. and Mohan, R. (2006). 3PL practices: an Indian perspective. International Journal of Physical Distribution \& Logistics Management, 36(9), pp. 666-689.

Sanyal, S. (2006b). Freight Hike Will Not Be Uniform on All Routes. Hindu Business Line. 8 June.

Sauvage, T. (2003). The relationship between technology and logistics third-party providers. International Journal of Physical Distribution \& Logistics Management, 33(3), pp. 236-253.

Sharma, S. K., Panda, B. N., Mahapatra, S. S., and Sahu, S. (2011). Analysis of barriers for reverse logistics: an Indian perspective. International Journal of Modeling and Optimization, 1(2), pp. 101.

Singh, M. D. and Kant, R. (2008). Knowledge management barriers: An interpretive Structural modeling approach. International Journal of Management Science and Engineering Management, 3(2), pp. 141150.

Singh R. K., Garg, S. K, Deshmukh, S. G. and Kumar, M (2007a). Modeling of critical success factors for implementation of AMTs'. Journal of Modelling in Management, 2(3), pp. 232-250.

Singh R. K., Garg, S.K. and Deshmukh, S.G. (2007b). Interpretive Structural Modelling of factors for improving competitiveness of SMEs. International Journal of Productivity and Quality Management, 2(4), pp. 423-440.

Tezuka, K. (2011). Rationale for utilizing 3PL in supply chain management: A shippers' economic perspective. IATSS Research, 35(1), pp. 24-29.

Thai, V. V., Cahoon, S., and Tran, H. T. (2011). Skill requirements for logistics professionals: findings and implications. Asia Pacific Journal of Marketing and Logistics, 23(4), pp. 553-574.

Venkatesh,V. G., Zhang, A., Luthra, S., Dubey R., Subramanian, N. and Mangla, S. (2017), 'Barriers to coastal shipping development: An Indian perspective', Transportation Research Part D: Transport and Environment, 52, Part A, pp. 362-378.

Warfield, J. W. (1974). Developing interconnected matrices in Structural Modeling. IEEE Transcript on Systems, Men and Cybernetics, 4(1), pp. 51-81.

Mrs. Anchal Gupta is doing PhD in Management from Delhi School of Management, Delhi Technological University, Delhi, India. Her interest is in Supply Chain Management, Logistics Management and Service Quality Management. She has published many research papers in reputed national and international journals and conferences. 
Dr. Rajesh K. Singh is Professor in Operations Management area at Management Development Institute, Gurgaon, India. His areas of interest include Supply Chain Management, Small Business Management and Quality Management. He has published around 125 research papers in reputed international/national journals and conferences. His papers have appeared in journals such as Production Planning and Control, Journal of Industrial and Production Engineering, Industrial management and Data Systems, Singapore Management Review, International Journal of Productivity and Performance Management, Benchmarking: An International Journal, Journal of Modelling in Management, Competitiveness Review, Global Journal of Flexible Systems and Management, Journal of Advances in Management Research, International Journals of Productivity and Quality Management, International Journal of Services and Operations Management, Management Research Review, IIMB Management Review etc.

Pradeep Kumar Suri is serving as a Professor in the Delhi School of Management, Delhi Technological University (DTU). $\mathrm{He}$ is originally from the 1986 batch of the Indian Statistical Service. Prior to joining the DTU in 2012, he served as Senior Technical Director at the National Informatics Centre (NIC), Government of India. He joined NIC during 1993, where he served in different capacities during the life cycle of several ICT-based projects in the agriculture and allied sectors. In particular, He has been the NIC National Coordinator for establishing Agriculture Marketing Information System Network (AGMARKNET) linking about 3000 agricultures produce wholesale markets in India. The system has created opportunities for developing ICT enabled supply chains for various agricultural commodities. He is PhD in Management from IIT Delhi. He has publications in both national and international journals and providing consultancy support to Government and UN FAO. 